\title{
Divestment of Private Equity in Europe in the Years 2007-2013
}

\author{
Raffaele Visconti ${ }^{1} \&$ Giuseppe Freda ${ }^{2}$ \\ ${ }^{1}$ University of Naples Federico II, Naples, Italy \\ ${ }^{2}$ Naples, Italy \\ Correspondence: Raffaele Visconti, University of Naples Federico II, Naples, Italy. E-mail: ravisco@libero.it; \\ raffaele.visconti@unina.it
}

Received: December 4, 2014

Accepted: December 22, 2014

Online Published: January 25, 2015

doi:10.5539/ibr.v8n2p121

URL: http://dx.doi.org/10.5539/ibr.v8n2p121

\begin{abstract}
Using the data from the website of EVCA, the European Private Equity and Venture Capital Association, we provide an analysis of the divestment transactions made by Private Equity and Venture Capital in Europe in the period from 2007 to 2013.

The purpose of the research is to verify whether the amount of divestments and the selection of exit strategies are influenced by the GDP growth rate of European Union and the performance of equity markets of European Union Member States.

We also highlight the importance of divestment phase, because it is only through its success that venture capital and private equity firms can realize capital gains.

The analysis has demonstrated a positive correlation between divestments realized in the period considered and the GDP growth rate of European Union, as well as between the amount of disposals made during the period analyzed and the development of the Eurostoxx50 index.
\end{abstract}

Keywords: private equity, venture capital, divestments, exit strategy, write off

\section{Introduction}

This research aims to analyze divestment transactions made by Private Equity and Venture Capital in Europe in the period from 2007 to 2013. We will examine the temporal distribution of these transactions, with regard to both the amounts realized during the period considered and the several exit strategies used. The data used for the research were collected from the website of EVCA, the European Private Equity and Venture Capital Association.

The purpose of this study is to verify the following research hypothesis:

1) The amount of divestments realized in the period considered is affected by the GDP growth rate of European Union.

2) The amount of divestments realized in the period considered is affected by the equity markets performance of European Union countries.

3) The several methods to exit the investment are affected by the GDP growth rate of European Union.

4) The several exit strategies are affected by the equity markets performance of European Union countries.

We believe that it should firstly be made clear the difference between the private equity and venture capital activity, as understood by the doctrine and by operators from the sector within the European context. The PE is a type of equity investment into private companies not listed on the stock exchange, with the aim to hold the shareholding for medium-long periods. A private equity investment is generally characterized by the purchase of minority shares of companies that have come through the startup stage. The VC differs from PE because the investments are focused on start-up companies. The PE and VC firms buy generally equity ownership in companies operating in innovative sectors of the economy or that want to use new technologies to produce existing goods and services or a innovative way to distribute them. The purpose of these investments is to realize capital gains by selling equity ownership at a price higher than the purchase price.

First, we will examine the main methods to get out of an investment that can be used by PE firms. Then we'll do 
a short assessment of economic literature on the topic. Lastly, we will proceed to the analysis of data to test the research hypothesis.

\section{The Main Exit Strategies}

\subsection{Trade Sale}

The widely used exit strategy is the trade sale. The PE firm sells its shares held in a company to a trade buyer, who usually is active in the same or parallel economic sectors as the company itself. The buyer is, in many cases, interested in obtaining the control on a legal or on a de facto basis of the company. For this reason, at the time of the initial investment, in the contractual arrangement are included clauses on the transfer of securities, in the event that those securities are not repurchased by the original control group. These are clauses that entail an obligation to sell at the same price agreed between PE firm and the new buyer or at a price based on a multiple of some predetermined parameters such as, for example, operating income, sales, etc. Indeed, the sale of a minority shareholding might be difficult or be concluded at a price that does not allow to achieve concrete value creation that has occurred during the holding period of the participation. In the event of the transfer of shares that allow the firm's control, the buyer would be willing to pay an higher price than the economic value of the target company, because profitable operational synergies could be created with his business. In addition, the company might have assets that might be of strategic importance to the buyer. This form of disinvestment could create problems between the management of the company and the new buyer, as it may cause the fear of losing their position in the company or otherwise that it might be substantially reduced.

\subsection{Sale to Another Private Equity House}

The sale of the shareholding to another PE firm can be based on many reasons. One of these is certainly represented by the smaller amount of time needed to conclude the transaction with another financial intermediary. The original investor would be very satisfied with the capital gains resulting from selling shares and may decide to spend the money on new investments with better future return prospects, measured by the internal rate of return (IRR). Because the private equity funds are of limited duration, as the deadline approaches PE firm might need to liquidate the investment in order to respect the obligation to repay capital raised at the time of initial subscription of the units (fundraising). This method could be supported by the management and the original control group, who might prefer a temporary investor in the company's capital. This is because might be interested in buying back the shareholding.

\subsection{Initial Public Offering - IPO}

Initial Public Offering (IPO) is a type of public offering whereby the company's shares are offered for sale to retail investors with the aim of creating a wide diffusion of the same in the investing public and allow their listing on stock market. This method may be used when company have come through the startup stage and has reached sufficient size to justify the listing. The IPO, as well as the stage of development of the company, is also influenced by the stock market trend which, in the event of a big increase in stock prices, allowing achievement of the transaction at prices that allow the initial investor to obtain substantial capital gains. However, it is necessary to emphasize that IPOs also have some disadvantages compared to other exit strategies. IPOs are difficult to achieve because of the strict regulatory requirements for the listing on a stock market. In addition, stock markets dedicated to medium-sized companies are poorly developed, with the exception of the Alternative Investment Market (AIM), a London Stock Exchange's market. The characteristic of the financial systems of continental Europe, more bank-oriented, make these operations insufficiently used. As will be shown below, data analysis suggests that other types of disinvestment are most widely used in this context.

\subsection{Repayment of Principal Loans}

The original control group of the company buys back the shareholding held by the PE firm. This is a fairly common case, particularly when the initial action of the institutional investor is intended to resolve issues relating to business succession. In this case, family members who have maintained their equity stake in the company and have continued to manage it, may have an interest in buying back the shares. Usually, the financial resources for the purchase are derived from sale of assets belonging to the personal wealth or by using Leveraged Buy Out (LBO) transactions. The same applies when the initial investment of the PE firms has been made in order to fund company growth or to improve financial structures by reducing high levels of leverage.

\subsection{Sale to Management}

In this case, the shareholding is sold by a private equity investor to management of the company itself which, also buying the share capital held by original control group, may continue the business activity and keep, in this way, their positions in the company. Here too, the transaction could be achieved through Leveraged Buy Out 
transactions.

\subsection{Write Off}

The write-off is a total or partial reduction of the book value of the shareholding as a result of loss of the economic value of the investment. Therefore, this is not really an exit method, even if it shall have equal effect as a divestment. It is quite common in venture capital operations, given the high risk-return that distinguishes these operations. In this particular case, the reduction of the book value of the shareholding is more common due to the failure of business project.

\section{Literature Review}

Researchers have dwelt mostly on decisions concerning the selection of investments and their monitoring. To date, there aren't many theoretical and empirical analysis of the divestment transactions. This is because of the increased difficulty in the search of data concerning transactions made by each private equity funds. In particular, the collection of data on the IPOs is relatively simple. Instead, there are more difficulties with other exit methods, for which it is necessary to use global data collected by national and international professional associations.

The beneficial impact of the PE on the development of business activity and on economic growth has been emphasized in many studies, such as the research carried out by Champenoise and others (2009).

Many studies show that the PE firms, through adequate monitoring activities, play an important role in reducing information asymmetries, which influence investment and disinvestment decisions (Amit et al., 1999). The divestment decisions may be analyzed through two important elements. The first is the duration of the investment, the second is the exit method used. In the literature, these two aspects have been analyzed by authors (Giot \& Schwienbacher, 2007) who have highlighted the differences between the US market and the European market. An authoritative doctrine (Gompers, 1996) has highlighted that the purchase of shareholding by PE firms often takes place in successive stages. This makes it possible to obtain vast amounts of information, in addition to those available in the public domain, that allow for better monitoring of investment and offer an opportunity for financial intermediary to abandon the initial investment project, with a reduction in overall risk. Other scholars (Kaplan and others, 2003) point out that the PE firms insert in their contracts clauses on the composition of the main company bodies, the rights to information, etc. What is particularly interesting, in the context of this research, are those clauses with regard to the co-sale rights and obligations, in order to facilitate the exit or to offer divestment contract conditions more favorable for the seller. Other authors (Black B. S. \& Gilson R. J., 1999) have demonstrated, through a research on the US capital market, that IPOs represented the most profitable exit strategy, with yields near $60 \%$ threshold. It is necessary to consider that, when he sells his share ownership, the controlling shareholder of subsidiary company, as well as the economic value, has to give up advantages of corporate control. This creates an "agency problem" (Jensen\& Meckling, 1976) between the controlling shareholder and PE fund that holds a qualified minority shareholding. A research (Schmidt, 2003) highlights the importance of the appropriate incentives to minimize these problems. The potential conflict of interest may also be extended to company managers, in particular when their work is not easily observable and monitored.

Some researchers (Andreas et al., 2005), through an analysis of the European PE market, assume that the use of borrowing may reduce this conflict of interests. A researcher (Douglas, 2008), analyzing the exit operations made in Canada in the years 1991-2004, shows that the success of these operations depends on the ability to reduce agency costs and information asymmetries between PE fund and the buyers of the company share sold. In the case of Trade Sale, the purchaser usually has both technical skills and financial resources to achieve or commission a third party a due diligence through which the strengths and weaknesses of company can be analyzed. The doctrine, with respect to business strategy, has long highlighted (Bain, 1956) as the market structure influence the behavior of market participants, which in turn has a decisive influence on the performance of the enterprise. The opportunities to sell the equity participation, for the PE firms, are extremely cyclical, they therefore seek to optimize their timing in order to maximize the return on investment. The doctrine (Darby \& Zucker, 2002) has shown a positive correlation between the market value of the company and the listing of the same company. More generally, many studies, including one by Cumming and others (2003), reveal a high cyclicality of the disinvestments, dependent on both macroeconomic factors and stock market developments.

\section{Data Analysis}

The examined data referring to the PE activity, as explained in the introductory paragraph, derive from the website of EVCA - European Private Equity and Venture Capital Association. The data relating to the rate of GDP growth in UE were downloaded from the Eurostat website. We detected the index values of Eurostoxx50, representative sample of major European listed companies operating within eurozone nations, from the site 
"yahoo finance".

Table 1. Divestment by private equity and venture capital (thousands of Euro)

\begin{tabular}{lcccccccc}
\hline & 2007 & 2008 & 2009 & 2010 & 2011 & 2012 & 2013 \\
\hline Divestment & 3217812 & 2419004 & 2132876 & 2080861 & 2366100 & 1851258 & 2231220 \\
GDP growt \% & 3.2 & 0.36 & -4.53 & 2.04 & 1.64 & -0.36 & 0.08 \\
Eurostoxx 50 & 4400 & 2448 & 2965 & 2793 & 2317 & 2636 & 3109 \\
Divestment by trade sale \% & 31.5 & 38.9 & 32.9 & 41.3 & 47.8 & 36.2 & 53.5 \\
Divestment by public offering \% & 20.7 & 7.1 & 15.4 & 13.2 & 13.9 & 4.8 & 13.5 \\
Divestment by write-off \% & 12.3 & 11.9 & 19.1 & 15.7 & 13.7 & 27.1 & 15.2 \\
Repayment of principal loans \% & 7.4 & 8.6 & 1.8 & 1.2 & 1.6 & 2.1 & 2.3 \\
Sale to management \% & 3.8 & 9.8 & 4.7 & 6.4 & 4.3 & 4.7 & 5.8 \\
\hline
\end{tabular}

Source: Our elaboration from database of the EVCA.

Table 2. Correlation analysis

\begin{tabular}{lcc}
\hline & GDP growt $\%$ & Eurostoxx 50 \\
\hline Divestment & 0.54 & 0.77 \\
Trade sale & 0.18 & -0.41 \\
IPO & 0.22 & 0.74 \\
Write off & -0.47 & -0.24 \\
Repayment of principal loans & 0.32 & 0.38 \\
Sale to management & -0.02 & -0.43 \\
\hline
\end{tabular}

Source: our elaboration.

The analysis of data shows a moderate positive correlation $(+0.54)$ between the divestments made during the period considered and the GDP growth rate of European Union. In 2007, the year in which the amount of divestments has the highest value, the Europe GDP growth stood at $3.2 \%$, the highest value in the period 2007-2013. Their value has declined drastically in the course of the years 2008-2010, in conjunction with the slowdown in economic growth in UE. They showed an uneven trend for the subsequent three years. In the writer's opinion, a probable explanation for this could be due to the fact that economic and financial performance of the enterprises is better during the years of economic growth. In addition, a favorable economic environment and economic growth expectations generate a positive sentiment on future prospects for economic development and profitability of participating interests. For the reasons stated above, these institutional investors are able to achieve in this context substantial capital gains from the sale of their participations and, therefore, they are encouraged to make more disposals. Among other things, the high prices required to concluding such transactions, increase the total amount of this operations. These considerations are of a more general nature and may on no account be associated to individual PE firm. Therefore, our own first research hypothesis is confirmed by data analysis, at least partially.

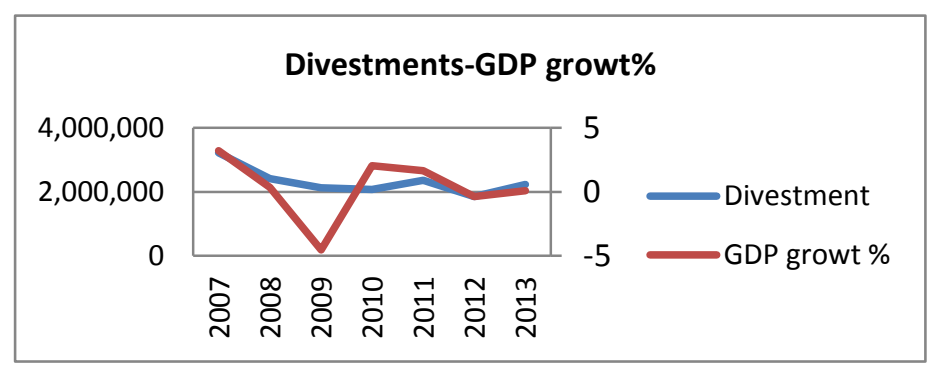

Figure 1. Divestments and GDP growth rate trend

As regards the second hypothesis, the analysis shows that there is a strong positive correlation $(+0.77)$ between the amount of disposals made during the period considered and the development of the Eurostoxx 50 index. The 
positive trend in stock markets is determined by enhanced economic performance of the enterprises, both current and prospective, and by a positive sentiment among investors. This involves that the shareholdings are evaluated on the basis of higher valuation ratios such as, for example, price-earning, price-cash flows, price-book value. This also applies to non-listed companies through the comparable companies approach.

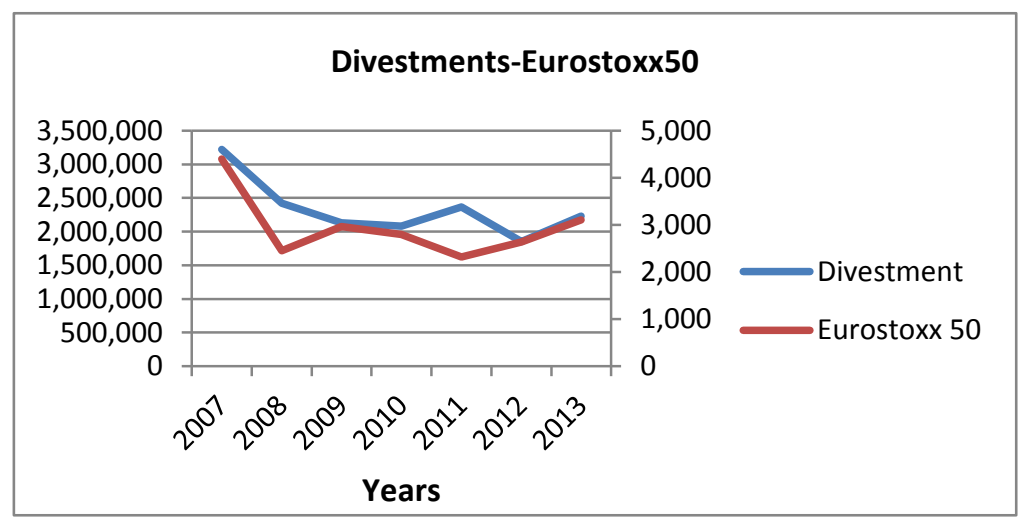

Figure 2. Divestments and Eurostoxx50 trend

The correlation between the GDP growth rate and the main exit methods is analyzed below. The analysis of data shows a positive correlation between the GDP growth rate and the Trade Sale $(+0.18)$. In view of the scarce significance of this level of correlation, we cannot express opinions. There is also a low level of positive correlation $(+0.22)$ with the IPOs. In this case too it is a not very significant value. It should however be stressed that in 2007, year of highest economic growth compared to those examined, there is the highest percentage of exit made with this method $(20.7 \%$ of the total amount of disposals made in the year). This is nevertheless a research hypothesis that is only partly confirmed. In fact, it is not always confirmed in the other years considered.

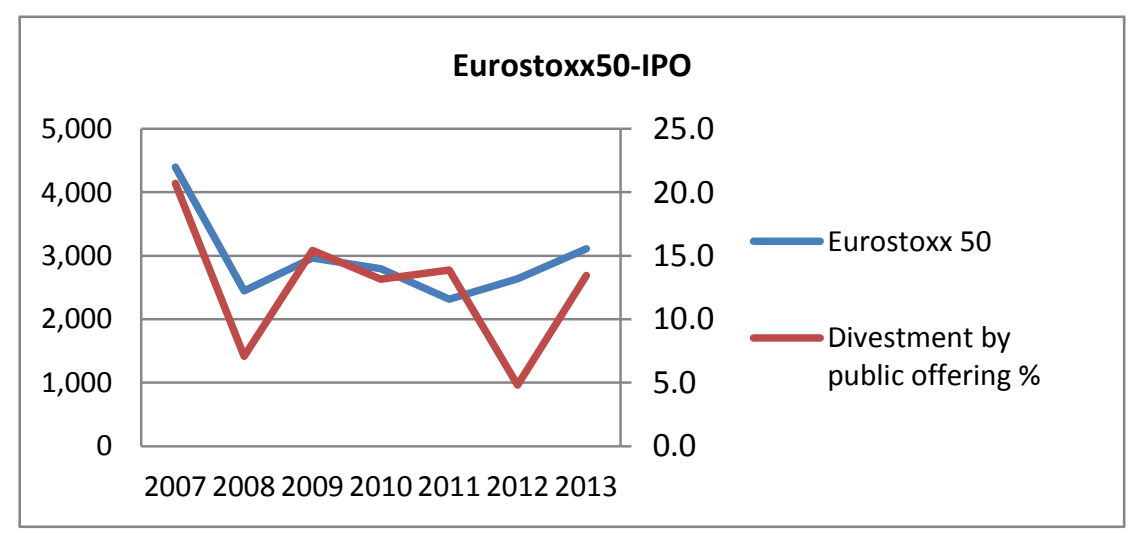

Figure 3. Eurostoxx50 and IPO trend

The correlation between the Write-off and the GDP growth rate is negative (-0.47). The explanation for this phenomenon comes from the fact that the number of investee companies by PE firms, whose economic value is cancelled or declines considerably, tends to decrease during periods of economic growth. On the contrary, the number of companies, that suffer significant decreases in their market values, increase during downturns or in phases of weak economic growth. In these cases, PE firms will be forced to reduce or cancel the value of these holdings in the portfolio. 


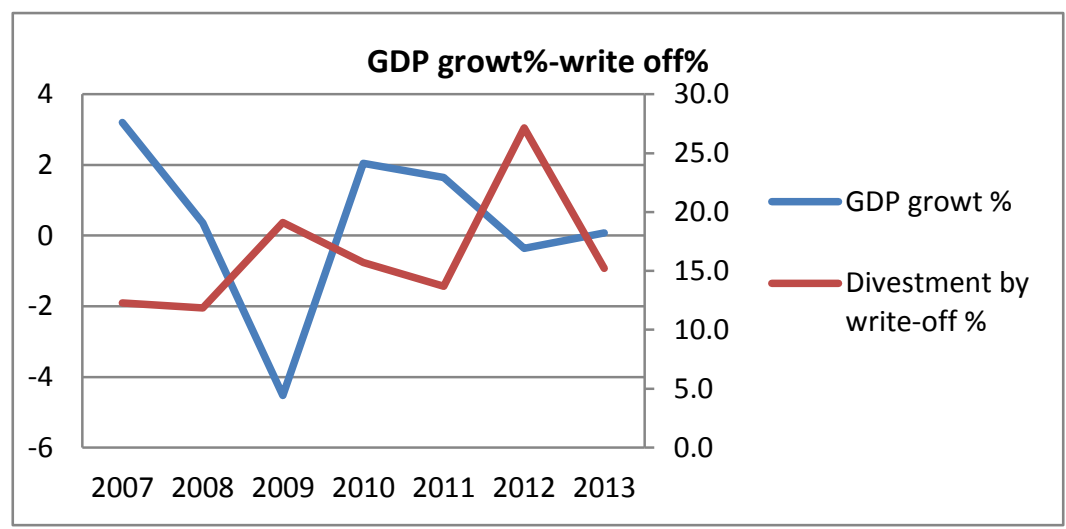

Figure 4. GDP growth rate and write off trend

There is a moderate positive correlation (+0.32) between the GDP growth rate and the repurchase of the interest by the original control group. This is probably due to the fact that the reference shareholder, encouraged by a positive economic trend, has a greater incentive to repurchase the shareholding held by an financial investor. The level of correlation between the rate of economic growth and the purchase of shareholding by the management of the company is virtually nil (-0.02).

The correlation between the Trade Sale and the Eurostoxx50 index is negative (-0.41). A possible explanation for this could be that entrepreneurs operating in the same sector might be reluctant to purchase the equity investment at higher prices. Indeed, these individuals have more knowledge about the growth and profitability potential of the sector in question. In addition, they are in the best position to evaluate the strengths and weaknesses of the company and, therefore, have greater technical competence to determine the true economic value of the company. Consequently, PE firm has to make other types of exit.

There is a strong positive correlation between the IPOs and the Eurostoxx50 index. During periods characterized by an increase in market indices, it's more profitable for the financial investor placing securities with retail investors, in order to allow the listing on stock market. This phenomenon may be due to excess of investor optimism, which can be explained through behavioral finance theory.

The analysis of data shows a negative correlation between the Write off and the development of the Eurostoxx50 index (-0.24). However, this value is not very meaningful and therefore it doesn't allow to formulate relevant hypothesis.

In addition, the research has highlighted that there is a positive correlation $(+0.38)$ between the development of the Eurostoxx50 index and the divestment implemented through the repurchase of the interest by the original control group. This can be explained by the circumstance that the increase in the index, which reflects also the higher results expected future, determines the decision by the control group to repurchase the shareholding. It should be pointed out here that this operation could also have advantages for the control group itself, taking into account that often the parameters for determining the price are defined in the sales contract from the beginning of the transaction.

Finally, the correlation between the Eurostoxx 50 index and the purchase of shares by the management is negative (-0.43). Despite an increase in the index could determine the will of the management to purchase the shareholding, it is must be emphasized that such an operation would entail a substantial capital investment. Therefore, including through the use of leverage, management could think that the investment is not realizable.

\section{Conclusion}

The venture capital and private equity divestment processes represent an extremely delicate phase, which requires particular attention because the outcome of the transaction determine the realization of capital gains. The most important aspects for the definition of a exit strategy are the individuation of the best time to divest and the identification of the most appropriate exit method. Naturally, the actual realization of the strategy is affected by the performance of the investee company and its sector of activity, as well as the financial markets.

The main goal of this research is to show whether the amount of divestment and the exit strategies are influenced by the development of the EU GDP growth rate and the performance of equity markets of European Union Member States. 
The analysis carried out has demonstrated a moderate positive correlation between divestments realized in the period considered and the GDP growth rate of European Union, as well as between the amount of disposals made during the period analyzed and the development of the Eurostoxx50 index. This can be explained by the circumstance that greater economic growth generates a positive sentiment regarding the future prospects for development and profitability of the investee companies, such as to allow higher capital gains from the sale of the held participations.

With regard to the relation between the various exit methods and the development of the GDP growth rate of European Union, as well as the performance of equity markets of European Union Member States, research has shown that there is a strong positive correlation between the IPOs and the Eurostoxx 50 index. This phenomenon could be explained by an excess of investor optimism about future prospects for economic growth and profitability of the undertakings concerned.

A final consideration concerns the different sign of the correlation coefficient relating to the relationship between the development of the Eurostoxx 50 index and the repurchase by the original control group, on the one hand, and the purchase of shareholding by the management of the company, on the other hand. In fact, the correlation between the index and the repurchase by the original control group is positive, while it is negative in the case of repurchase by the management. A possible explanation for this could be that the management, in order to obtain a controlling interest, should support a capital investment which is excessive compared to the true economic value of the company.

\section{References}

Amit, R., Brander, J., \& Zott, C. (1999). Why do venture capital firms exit? Theory and Canadian evidence. Journal of Business Venturing, 13, 441-466. http://dx.doi.org/10.1016/S0883-9026(97)00061-X

Andres, C., Betzer, A., \& Hooman, M. (2005). Going private via LBO-Shareholders gains in the European markets. Retrieved from http://www.ssrn.com

Bain, J. (1956). Barriers to new competition, their character and consequences in manufacturing industries. Harvard University Press, 329.

Bessler, W., \& Kurth, A. (2005). Exit strategies of venture capitalists in hot issue markets: Evidence from the "Neuer Markt" in Germany. Journal of Entrepreneurial Finance and Business Ventures, 10(1), 17-51.

Black, B. S., \& Gilson, R. J. (1999). Does venture capital require an active stock market? Journal of Applied Corporate Finance, 11(4) 36-48. http://dx.doi.org/10.1111/j.1745-6622.1999.tb00512.x

Champenois, C., Engel, D., \& Heneric, O. (2009). The birth of german biotechnology industry: Did venture capital run the show? Discussion Paper No. 04.

Cumming, D. (2008). Information asymmetries, agency costs and venture capital exit outcomes. Venture Capital, An International Journal of Entrepreneurial Finance. http://dx.doi.org/10.1080/13691060802151788

Cumming, D., Fleming, G., \& Schwienbacher, A. (2003). Liquidity of exit markets and venture capital finance. Mimeo, University of Amsterdam 22.

Darby, M. R., \& Zucker, L. G. (2002). Going public when you can in biotechnology. National Bureau of economic research, working paper, No. 8954. http://dx.doi.org/10.3386/w8954

Giot, P., \& Schwienbacher, A. (2007). IPOs, trade sales and liquidations: modelling venture capital exits using survival analysis. Journal of Banking \& Finance, 31, 679-702. http://dx.doi.org/10.1016/j.jbankfin.2006.06.010

Gompers, P. A. (1996). Grandstanding in the venture capital industry. Journal of Financial Economics, 42(1), 133-156. http://dx.doi.org/10.1016/0304-405X(96)00874-4

Jensen, M. C., \& Meckling, W. (1976). Theory of the firm: managerial behavior, agency costs and ownership structure. Journal of Financial Economics, 3, 305-360. http://dx.doi.org/10.1016/0304-405X(76)90026-X

Kaplan, S., \& Stromberg, P. (2003). Financial contracting theory meets the real world: An empirical analysis of venture capital contracts. Forthcoming in the Review of Economic Studies. http://dx.doi.org/10.1111/1467-937X.00245

Lerner, J., Sorensen, M., \& Stromberg, P. (2011). Private equity and long-run investment: The case of innovation. The Journal of Finance, 66(2), 445-477. http://dx.doi.org/10.1111/j.1540-6261.2010.01639.x

Ozmel, U., Robinson, D. T., \& Stuart, T. E. (2013). Strategic alliances, venture capital, and exit decisions in early 
stage high-tech firms. Journal of Financial Economics, 107(3), 655-670. http://dx.doi.org/10.1016/j.jfineco.2012.09.009

Schmidt, K. M. (2003). Convertible securities and venture capital finance. Journal of Finance, 43, $1139-1166$. http://dx.doi.org/10.1111/1540-6261.00561

Wright, M., \& Jelic, R. (2011). Exits, performance, and late stage private equity: The case of UK management buy-outs. $\quad$ European $\quad$ Management, $\quad$ 17(3), http://dx.doi.org/10.1111/j.1468-036X.2010.00588.x

\section{Copyrights}

Copyright for this article is retained by the author(s), with first publication rights granted to the journal.

This is an open-access article distributed under the terms and conditions of the Creative Commons Attribution license (http://creativecommons.org/licenses/by/3.0/). 